\title{
Regional Optimal Crop Planning for Sustainability in North- Eastern Dry Zone of Karnataka
}

\author{
G.V. Rohith, M. Sagar and Jaganath Olekar
}

Department of Agricultural Economics, University of Agricultural Sciences, Bengaluru-5600 65, Karnataka, India

*Corresponding author: rohithgv789@gmail.com (ORCID ID: 0000-0003-0978-6049)

Received: $17-12-2019$

Revised: $23-03-2020$

Accepted: 27-05-2020

\begin{abstract}
This study is aimed at designing the sustainable regional crop planning for North-Eastern Dry Zone (NEDZ) of Karnataka. The extent of efficiency in resource use and allocation as reflected in the costs incurred and net returns realized by valuing inputs at market prices, economic prices, natural resource valuation technique (NRVT) are quantified for Manvi and Raichur taluks of Raichur district in NEDZ of Karnataka. A random sample of 30 farmers each under rainfed condition, borewell irrigation and canal irrigation are studied. The study shows that optimal crop plan under market prices, it is not profitable to cultivate cotton under both canal and borewell irrigation. The area allocated to cotton under borewell condition instead of paddy when economic pricing was considered. This is due to less water requirement in cotton (49.4 acre inches per ha) than paddy ( 98.8 acre inches per ha).The area allocated for rainfed Redgram is higher in NRVT (69956 ha) than at economic price and market prices (31072 ha). This is due to higher net returns realized due to nitrogen fixation. Sustainable optimal crop plan for the region developed using linear programming technique indicated that, 168293 ha is to be allocated in canal, 457328 ha for rainfed, but no area allocated for borewell irrigated condition. Total optimum area allocated was 625621 ha which maximized net return to ₹ 1185 crores for Raichur District in the NEDZ of Karnataka. Crops cultivated under borewell condition were not profitable and sustainable because of higher cost of groundwater and also environmentally unproductive by looking into NRVT with water cost.
\end{abstract}

\section{Highlights}

( Policy makers can make use of the optimum regional crop plan developed to restrict the production of output which faces the problem of recurrent production and over production through support schemes and other fiscal incentives and disincentives.

(0 The developed optimum region crop plan also helps to optimum and sustainable use of resources and which improves the quality life of farmers.

Keywords: Optimal crop planning, market \& economic prices, natural resources valuation techniques, sustainability

Crop area allocated to different crops by farmers depends upon, inter alia market forces for specific crops dictated by road, rail, vehicular infrastructure, rural-urban influence, availability of water resource, especially groundwater, availability of electricity for pumping groundwater, on farm endowments of the farmers, degree of awareness and exposure to agricultural technology, access to credit and information, extent of rainfall, temperature and other climatic factors, extent of subsidies received and used. However, the extent to which the principle of comparative advantage determines or dictates the crop pattern and land use is an economic puzzle. While agro climatic, socio economic, and biophysical factors rule the cropping pattern, the extent of technical, allocative and economic inefficiencies

How to cite this article: Rohith, G.V. Sagar, M. and Olekar, J. (2020). Regional optimal crop planning for sustainability in north-eastern dry zone of Karnataka. Economic Affairs, 65(2): 241-247.

Source of Support: None; Conflict of Interest: None 
differ depending upon the crop, region, farmers, access to irrigation and other factors. There are no compelling reasons to accept that prima facie there is efficiency across all farmers and all crops.

Due to market price distortions influenced by the extent of subsidies offered to fertilizer, water, credit, and other inputs, price support offered to food crops, the efficiency of crop pattern and resource allocation is bound to be affected. On the other hand, subsidies for vital inputs are also required in order that the area / region / country do not suffer from food insecurity. However, food and livelihood security should not be at the cost of inefficiency in resource use, resource allocation, loss of efficiency, indiscriminate use of natural resources such as land, water and environment affecting sustainability. Again, this does not imply that there is gross inefficiency in allocation of all the resources and that addressing market imperfections alone is a panacea for all the economic illnesses faced by the farmers. This study is aimed at exploring the profitability of crops in Karnataka in general and in North-Eastern Dry Zone of Karnataka in particular in order to estimate the extent of inefficiency in resource use and allocation as reflected in the costs incurred and net returns realized valuing the inputs at market prices, economic prices, natural resource values such as fixation of atmospheric nitrogen and liberation of greenhouse gases, as well as costing or valuing water resource in general and groundwater resource in particular. The role of subsidies, price support to different crops, Governmental support to different regions / States played and is still playing a crucial and vital role addressing food security concerns. Due to these factors, currently India does not face the food shortage. The question of starvation death which was prevalent during the times of acute food shortage is now in oblivion. Thus, India did emphasize on augmenting food production through incentivizing farmers. The farmers in the country rapidly responded to this call and facilitated the Government to overcome food shortages and currently India is a reasonable position with respect to food. Thus, during the green revolution and immediate post green revolution periods, result oriented strategy towards quick growth in production took the stage and became more important than agro economic factors, suitability and natural resource endowments. Thus, crop pattern changes and crop shifts in 1970's served the social objective and in the process, the principle of efficiency and comparative advantage are sacrificed to some extent. With the result, Punjab now cultivates rice crop while rice was being cultivated in regions of hot climate coupled with canal water availability. Thus, rice has spread in such areas where it was never found earlier. Similarly, sugarcane is being cultivated in areas where surface water is not abundant, but groundwater is extracted to cultivate sugarcane. These indicate that the market distortions influenced by subsidies and price support offer non-natural advantages to cultivate different crops in different periods. Obviously these crops were never grown earlier as the agro-climatic factors did not facilitate them, resulting in expensive ways of cultivating crops. The cost of cultivation of different crops and the returns realizable have also been influenced by non-market forces affecting the natural crop choice by farmers. The extent to which such crop choices are sustainable is a serious economic question and puzzle.

Due to crop choices which are natural resource intensive, it is in order to examine whether cultivation of such crops is equitable and sustainable. These are affecting the profitability of crops which in turn result in economically irrational crop choices, crop mixtures and enterprise combinations. Farmers are also finding it extremely difficult to sustain such input incentive crop pattern. An important economic reason for farmers' crop choice is also that the cost of vital input like surface water and groundwater is ignored / discounted, with the result that farmers while they incur investment on water, the expenditure is not taken into account in the cost of cultivation of crops. The present practices by farmers clearly demonstrate that the choice of crop pattern and cost of cultivation are subjective, lacking economic rationale. The extent of land degradation, secular overdraft of aquifers, negative externalities, are prima facie indicators of farmers' economically irrational behavior in agriculture. Accordingly it is in order that farmers are given information so that they would consider them to guide their crop planning and management in order that their actions are consistent with natural resource conservation, endowment so that they reach allocative, technical and economic 
efficiency including sustainability. Natural resource management for equity and sustainability is crucial for small and marginal farmers as their resource base is shrinking over years. Farm management is a crucial aspect for managing different natural resources. Thus, this underscores the importance of allocation of resources and distribution of crops considering sustainability and resource use efficiency. The overall impact of natural resource management with sustainability needs to reflect on the optimal crop pattern in consonance with natural resource availability along with resource endowments of farmers. Thus, this study is aimed at development of optimal crop plan with resource use efficiency and sustainability for North-Eastern Dry Agro-climatic Zone (NEDAZ) of Karnataka with the following specific objectives.

\section{MATERIALS AND METHODS}

Raichur district has been chosen in North-Eastern Dry Zone of Karnataka (NEDZ) for field work in two taluks namely Raichur and Manvi. The Random sampling method was adopted for the selection of sample farmers. Data were collected from 30 rainfed farmers, 30 farmers who are using groundwater and 30 farmers who are using canal irrigation. Thus total sample size comprised of 90 farmers. The farmers using underground water for irrigation was identified based on the criteria that 50 per cent of the total cultivated area was irrigated through underground water. Similar classification was made for the selection of the canal irrigated farmer where in which 50 per cent of irrigated area under total cultivated area is through canal irrigation. Likewise the rainfed farmers were identified if the cultivated area with no source of irrigation is more than 50 per cent of the total cultivated land. Simple tabular analysis technique was used to estimate cost and returns of crops in the North Eastern Dry Zone of Karnataka.

\section{Linear programming}

In linear programming analysis, linear function of a number of variables (objective function) is maximized (or minimized) subjected to number of constraints in the form of linear equalities or inequalities. In the present study it was employed to develop the optimum regional crop plan.

\section{Selection of the typical farm}

The average area under different crop (ha), labour utilization (man-days), water applied to crops (acre inch), capital expenditure (₹) excluding labour cost incurred and net returns realized by farmers with different sources of irrigation (canal and borewell) and rainfed were calculated, averaged and used for development of the optimum regional crop plan. The computational procedure is as follows:

\section{Mathematical formulation of model}

In mathematical form one year linear program can be expressed in the following way.

Maximize $Z=\sum_{i=1}^{n} N_{i} X_{i}$ for $\mathrm{i}=1,2,3,4 \ldots \mathrm{N}$ is the number of crops

Subject to the constraints,

$$
\begin{aligned}
& \text { 1. } \sum_{i=1}^{n} W_{i} X_{i} \leq W_{u}(i=1,2,3,4 \ldots . . N) \\
& \text { 2. } \sum_{i=1}^{n} X_{i} \leq I(i=1,2,3,4 \ldots \ldots \ldots . . N) \\
& \text { 3. } \sum_{i=1}^{n} X_{i} \leq R(i=1,2,3,4 \ldots \ldots . . N) \\
& \text { 4. } \sum_{i=1}^{n} X_{i} \leq C(i=1,2,3,4 \ldots \ldots . . N) \\
& \text { 5. } \sum_{i=1}^{n} X_{i} \geq F_{i}(i=1,2,3,4 \ldots \ldots \ldots . N) \\
& \text { 6. } \sum_{i=1}^{n} D_{i} X_{i} \leq L(i=1,2,3,4 \ldots \ldots . . N) \\
& \text { 7. } \quad \sum_{i=1}^{n} T_{i} X_{i} \leq B(i=1,2,3,4 \ldots \ldots . N) \\
& \text { 8. } \quad X_{i} \geq 0
\end{aligned}
$$

Where,

$Z$ = Total net return (₹) from all crops grown by the farmer in region,

$N_{i}=$ Net return from the $i^{i \text { th }}$ crop $(₹ /$ ha),

$X_{i}=$ Crop area under $i^{\text {th }}$ crop (ha) (decision variable)

$W_{i}=$ Water requirement for $i^{\text {th }}$ crop (ha $\mathrm{cm}$ )

$W_{u}=$ Total ground water availability $(\mathrm{ha} \mathrm{cm})$

$I=$ Borewell area availability for cultivation in the region

$R=$ Rainfed area availability for cultivation in the region

$C=$ Canal area availability for cultivation in the region

$F_{i}=$ Food requirement of $i^{\text {th }}$ crop in terms of area (ha)

$D_{i}=$ Labour requirement for $i^{\text {th }}$ crop (man-days/ha) 
$L=$ Total Agricultural labour availability per year in the region (District)

$T_{i}=$ Total cost required to produce $i^{\text {th }} \operatorname{crop}(₹ / \mathrm{ha})$

$B=$ Total budget availability of the farmer in the region (₹) or total cost of production per hectare of all crops multiplied with area under all crops.

\section{Objective function}

Objective function was to maximize aggregate net income from crops grown in the farm. The objective function was subject to linearity or non-negativity constraints which are presented above.

\section{Resource level and constraints}

\section{Ground water availability}

The total ground water availability for Raichur district was taken from the central ground water board as equal to 55760 ha meters which was converted to acre inch by taking conversion factor 1 hectare meter $=97.28$ acre inch which is equal to 5424332.8 acre inch per year for the district.

\section{Land area}

Land Area Availability and Utilization: Land is one of the limiting resources on all farm situations. It is defined as operational area, which was equal to owned-land plus leased-in land minus leased-out land. The average size of operational holding was 5.12 ha (rainfed farmers), 2.72 ha (borewell farmers) and 4.88 ha (canal farmers), totally the average size of operational land was 4.2 ha as from the data collected. The total area under rainfed in Raichur district was 405300 ha and with 168293 ha was the area under canal irrigation were taken as constraints for rainfed and canal irrigated crops respectively. Area under borewell irrigation was 11526 ha which was taken as limited, constraints for borewell irrigated crops cultivated in the district.

\section{Food production}

To fulfil the demand for grains and pulse to the increasing population, the paddy, redgram, Chickpea were taken as constraints equal to or more than the existing area under crop in the last year from DES data. Similarly sorghum as fodder to feed livestock was considered.

\section{Agricultural labour availability}

The labour availability for agriculture work was 269528 man days as per the district data 2011, multiplied with 180 days (Average working days of agricultural labour per year). The final agricultural labour availability was 48515040 days per year.

\section{Working Capital /Budget availability}

To calculate capital use on the farm, the costs of seed, manures, fertilizers, pesticides, insecticides, hiring of bullocks and machinery, irrigation charges, etc. were added up and the cash requirements for rainfed, borewell, canal crops were worked out separately. For estimating capital availability on the farm, it was assumed that the expenditure incurred on variable inputs was taken as per data collected from sample farmers from the respective crops and multiplied with the existing area of sample data which gives total capital availability to the entire district was 1026.87 Crore.

\section{Non-negativity constraints:}

The variables in the linear programs were must be greater than or equal to zero which should not be negative returns or inputs.

\section{RESULTS AND DISCUSSION}

\section{Regional crop planning taking market prices, economic pricing and NRVT with water cost of input and output in to consideration.}

The major crops cultivated in Raichur district and the constraints were subjected to linear programming in order to obtain the economic optimum cropping plan at market prices, economic prices and natural resource valuation including costing groundwater for irrigation. The area under paddy, redgram, and chickpea is fixed to meet the food requirements for the increasing population whereas Sorghum as fodder for the livestock as per the area under previous year from DES. The results presented in the Table 1 indicated that when market prices are considered, the optimal area allocated under canal irrigation is 1.6 lakh ha, while allocating 4.25 lakh ha under rainfed crops. The optimal crop plan suggested making use of 11 lakh ha $\mathrm{cm}$ of groundwater out of 54 lakh ha cm, 343 lakh man days of labour out of 485 lakh man days of labour. 
Table 1: Regional crop planning for Raichur District considering inputs and outputs at market prices, economic prices and NRVT approaches

\begin{tabular}{|c|c|c|c|c|c|}
\hline \multirow{2}{*}{ Particulars } & \multicolumn{3}{|c|}{ Allocated resources } & \multicolumn{2}{|c|}{$\begin{array}{l}\text { Constraints } \\
\text { Specification }\end{array}$} \\
\hline & Market prices & Economic prices & $\begin{array}{l}\text { NRVT with water } \\
\text { cost }\end{array}$ & & \\
\hline Canal irrigated area (ha) & 168293 & 168293 & 168293 & $\leq$ & 168293 \\
\hline Borewell irrigated area (ha) & 11526 & 11526 & 0 & $\leq$ & 11526 \\
\hline Rainfed area (ha) & 425035 & 429150 & 457328 & $\geq$ & 405300 \\
\hline Capital cost (crores) & 1026.87 & 1026.87 & 1026.87 & $\leq$ & 1026.87 \\
\hline Ground water Availability(Acre inches) & 1138768.8 & 570191.22 & 0 & $\leq$ & 5424332.8 \\
\hline Total agricultural labour availability (Man-days) & 34373599 & 34742222 & 34715876 & $\leq$ & 48515040 \\
\hline Paddy (ha) & 179819 & 168293 & 168293 & $\geq$ & 151707 \\
\hline Redgram (ha) & 31072 & 31072 & 69956 & $\geq$ & 31072 \\
\hline Chickpea (ha) & 109636 & 109636 & 109636 & $\geq$ & 109636 \\
\hline Sorghum (ha) & 109203 & 109203 & 109203 & $\geq$ & 109203 \\
\hline Total area allocated ha & 604854 & 608969 & 625621 & $\leq$ & 625621 \\
\hline Net return (Crores) & 1500.50 & 1249.20 & 1185.78 & & \\
\hline
\end{tabular}

Note 1: NRMP (Net returns based on market prices $)=$ Gross Income minus (Cost $\left.A_{2}+I V F L\right) ; N R E P($ Net returns based on economic prices $)$ $=$ NRMP minus (Fertilizer subsidy + Electricity subsidy), NRNRVT without water cost (Net returns based on Natural resource valuation technique without water cost $)=$ NREP + Nitrogen fixation value - GHS emission cost. NRNRVT with water cost (Net returns based on Natural resource valuation technique without water cost $)=N R E P+$ Nitrogen fixation value $-G H S$ emission cost-water cost; 2: Energy subsidy for canal irrigated crops ₹ 100 per acre of paddy, and ₹ 35 per acre for semi-arid crops; 3 . Energy subsidy for borewell irrigated crops same as that of energy cost of pumping = working hours of Irrigation pumpset * Horse power of the Irrigation pumpset * $0.75 \mathrm{KWH}$ * ₹ 3.5 per $\mathrm{KWH}$ ); 4: Fertilizer subsidy per $\mathrm{kg}$ of $\mathrm{N}_{2}=₹ 20.87$; that per $\mathrm{kg}$ of $\mathrm{P}_{2} \mathrm{O}_{5}=₹ 18.67$; per $\mathrm{kg}$ of $\mathrm{K}_{2} \mathrm{O}=₹$ 15.50.); 5 : $\mathrm{GHG}$ cost ₹ 0.463 per $\mathrm{kg}$ of $\mathrm{CO}_{2} ; 6$ : Surface water cost ₹ 3130 per ha for paddy, ₹ 1095 per ha for semi-arid crops; 7: Groundwater cost $₹ 200$ per acre inch water required 40 acre inch for paddy, 20 acre in for cotton, 12 acre inch for groundnut.

When economic prices are considered, the optimal area allocated under canal irrigation is 1.6 lakh ha, while allocating 4.29 lakh ha under rainfed crops. The optimal crop plan suggested making use of 5.70 lakh ha $\mathrm{cm}$ of groundwater out of 54 lakh ha cms, 347 lakh man days of labour out of 485 lakh man days of labour. When natural resource valuation and costing of groundwater are considered the optimal area allocated under canal irrigation is 1.6 lakh ha, while allocating 4.57 lakh ha under rainfed crops. The optimal crop plan suggested without using groundwater out of 54 lakh ha cm, 347 lakh man days of labour out of 485 lakh man days of labour.

The regional crop planning of Raichur district by considering different approaches, results indicated that higher net returns were realized by market prices compared to economic and NRVT with water cost by allocated area of 604854 ha under market prices, 608969 ha under economic prices, entire area under NRVT with water cost of 625621 ha. Area allocated for the paddy cultivation (179819 ha) is more in market prices compared to economic (168293 ha) and NRVT with cost (168293) which is also more than area under constraints (151707 ha). The area allocated in red gram cultivation was increased in NRVT with water cost compared to market prices and economic prices than the constraints area allocated area to redgram cultivation. There is no changes in area allocated for chickpea (109636 ha), sorghum (109203 ha), for markets prices, economic prices and NRVT with water cost. Allocated canal area is same in all three approaches and area under borewell irrigated is not allocated for NRVT with water cost. The area under rainfed cultivation was increased in all approaches than the area under rainfed constraints.

\section{Regional optimum allocated area for crops taking market prices, economic pricing and NRVT with water cost of input and output in to consideration}

The results presented in the Table 2, indicated that when market prices are considered, the optimal crop plan included rainfed cotton, sorghum, canal 
Table 2: Regional optimum allocated area for Raichur District considering inputs and outputs at Market prices, economic prices and NRVT approaches

\begin{tabular}{llllllll}
\hline & \multicolumn{2}{c}{ Market prices } & \multicolumn{2}{c}{ Economic prices } & \multicolumn{2}{c}{$\begin{array}{c}\text { NRVT with groundwater } \\
\text { cost }\end{array}$} & $\begin{array}{l}\text { Area under } \\
\text { crop as per }\end{array}$ \\
\cline { 2 - 7 } Crops & $\begin{array}{l}\text { Net returns } \\
\text { (₹ per ha) }\end{array}$ & $\begin{array}{l}\text { Optimal } \\
\text { area (ha) }\end{array}$ & $\begin{array}{l}\text { Net returns } \\
\text { (₹ per ha }\end{array}$ & $\begin{array}{l}\text { Optimal } \\
\text { area (ha) }\end{array}$ & $\begin{array}{l}\text { Net } \\
\text { returns }\end{array}$ & $\begin{array}{l}\text { Optimal area } \\
\text { (₹ per ha) }\end{array}$ & $\begin{array}{l}\text { DES (ha) } \\
\text { Cotton (RF) }\end{array}$ \\
\hline 24424 & 175124 & 20478 & 179239 & 20428 & 168533 & \\
Cotton (Canal) & 33704 & 0 & 28786 & 0 & 27612 & 0 & 53360 \\
Cotton (BW) & 40442 & 0 & 34037 & 11526 & 24079 & 0 & \\
Sorghum (RF) & 9088 & 109203 & 7602 & 109203 & 7575 & 109203 & 109203 \\
Paddy (Canal) & 44133 & 168293 & 36426 & 168293 & 31397 & 168293 & 151707 \\
Paddy (BW) & 49576 & 11526 & 38390 & 0 & 16731 & 0 & 31072 \\
Redgram (RF) & 14375 & 31072 & 12161 & 31072 & 13205 & 69956 & 109636 \\
Chickpea (RF) & 11766 & 109636 & 9570 & 109636 & 12250 & 109636 & 67767 \\
Sunflower (RF) & 6395 & 0 & 3908 & 0 & 3866 & 0 & 52357 \\
Bajra (RF) & 3735 & 0 & 1459 & 0 & 1431 & 0 & 43532 \\
Groundnut (BW) & 19782 & 0 & 15747 & 0 & 10907 & 0 & \\
\hline
\end{tabular}

and borewell irrigated paddy, rainfed redgram and chickpea and excluded canal and borewell irrigated cotton, rainfed sunflower and rainfed Bajra, totaling to 6.04 lakh ha out of 6.25 lakh ha of area..

When economic prices are considered, the optimal crop plan included rainfed and borewell irrigated cotton, rainfed sorghum, canal irrigated paddy, rainfed redgram and chickpea and excluded canal irrigated cotton, borewell irrigated paddy, rainfed sunflower and rainfed Bajra, totaling to 6.08 lakh ha out of 6.25 lakh ha of area. The results indicated that when natural resource valuation and costing of groundwater are considered, the optimal crop plan included rainfed cotton and sorghum, canal irrigated paddy, rainfed redgram, rainfed chickpea and excluded canal and borewell irrigated cotton, borewell irrigated paddy and borewell irrigated groundnut, rainfed sunflower and Bajra, totaling to 6.25 lakh ha out of 6.25 lakh ha of area. The highest area was allocated to cotton (175124 ha) under rainfed situation compared to sorghum, redgram, chickpea, sorghum when considered in all three approaches. The canal irrigated area is allocated by only paddy crop rather than cotton because of higher net return realized by farmers. Area allocated to paddy with canal situation is same in three approaches. The changes were found in area allocated with groundwater condition, in case of market prices area allocated to the cotton, in case of economic prices area allocated to the paddy and no area allocated to any crops when considering NRVT with water cost.

\section{CONCLUSIONS}

Regional optimum crop plan for district indicates that there is changes in canal irrigated area in all three approaches like net returns realized by economic prices, net returns realized by economic prices and net returns realized by natural resources valuation. The area under borewell irrigation is allocated by looking into market and economic approaches only. The area approach didn't look into NRVT with water cost which indicates that the crops were grown in borewell condition. The NRVT with water cost is not so profitable under borewell irrigated area because of higher ground water cost and also unsustainable. The area allocated to rainfed condition has increased in NRVT with water cost and economic price when compared to market price. This is because of environmentally safe nature of pulses, higher net returns were realized by nitrogen fixation.

\section{REFERENCES}

Chaitra, B.S. and Chandrakanth, M.G. 2005. Optimal extraction of groundwater for irrigation: synergies from surface water bodies in tropical India. Water Policy Journal, 7: 597-611.

Dey, G. 2011. Optimum allocation of resources in vegetable cultivation. Journal of Crop and Weed Science, 7(1): 77-80. 
Gadge, S.B., Gorantiwar, S.D., Virendra Kumar and Mahesh Kothari. 2011. Optimal cropping pattern for adoption of micro-irrigation methods in canal command area - A case study. Journal of Applied Engineering, 48(1).

Laxmi Narayan Sethi, Nagesh Kumar, D., Sudhindra Nath Panda and Bimal Chandra Mal. 2002. Optimal crop planning and conjunctive use of water resources in a Coastal River Basin. Water Resources Management, 16: 145-169.

Mahendran, R., Chandrasekaran, M. and Gurunathan, S. 2006. A Study on evolving optimal cropping patterns in ground water over-exploited region of Perambalur district of Tamil Nadu. Agricultural Economics Research Review, 19: 95-108

Manjunatha, A.V., Speelman, S., Chandrakanth, M.G. and Van Huylenbroeck, G. 2011. Impact of groundwater markets in India on water use efficiency: A data envelopment analysis approach. Journal of Environmental Management, 3:1-6

Nagaraj, N., K., Shankar and Chandrakanth, M.G. 2003. Pricing of irrigation water in Cauvery basin: Case of Kabini Command. Economic and Political Weekly, pp. 4518- 4520 .
Pardis, 2014. Assessment of carbon footprint of agriculture production system of Karnataka and Afghanistan. Ph.D. (Agri) Thesis (Unpub.), Department of Forestry and Environmental Sciences, University of Agricultural Sciences, Bengaluru.

Shinde, S.E., Ingle, P.M., Mane M.S., Thokal R.T. and Ayare B.L. 2015. Optimal Cropping Pattern for Sustainable Water Use in Canal Command Area. Research Journal of Recent Sciences, 3(4): 25-28.

Varalakshmi, K., Jayashree Handigol and Yeledhalli, R.A. 2011. A study on optimum crop enterprise mix for the farmers in Kurnool district of Andhra Pradesh. Karnataka Journal of Agricultural Sciences, 24(5): 661-667.

http://cgwb.gov.in/District_Profile/karnataka/RAICHURE_ BROCHURE.pdf

http://www.raichur.nic.in/DSO/RaG (2012-13).pdf

http://fert.nic.in/implementation-nutrient-based-subsidynbs-policy-phosphatic-and-potassic-pk-wef-01042014nbs-policy

http://waterresources.kar.nic.in/index.asp 
